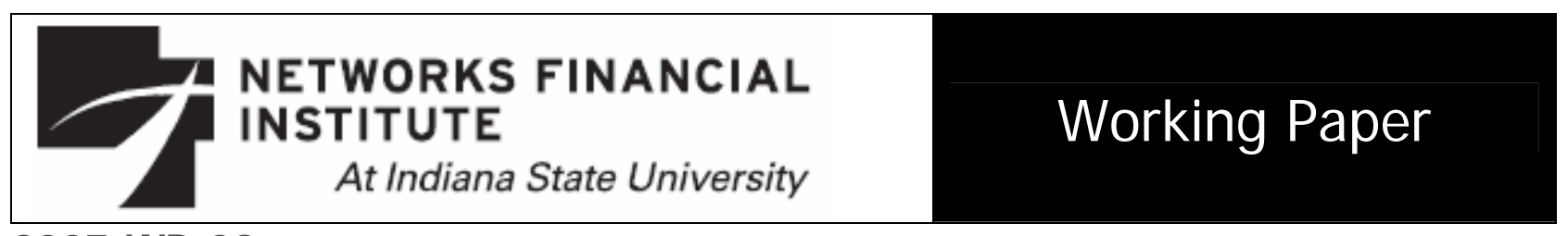

2007-WP-08

February 2007

\title{
An Analysis of Financial Preparation for Retirement
}

M. Kabir Hassan and Dr. Shari Lawrence

Abstract: In this study, we analyze financial preparation for retirement. Specifically, probit analysis was conducted using data from the Survey of Consumer Finances to compare and contrast variables affecting retirement preparation between men and women aged thirty to thirty-nine. We specifically analyze two dependent variables: whether or not an individual is eligible for a retirement plan and whether or not an individual is contributing to a retirement plan.The findings indicate that good health and work history have significant positive effects on retirement plan eligibility whereas age and education levels have significant negative effects. Regarding retirement plan contributions, the findings indicate significant positive effects regarding income and womenhood. Therefore, the findings generally support the hypothesis of income as a predictor of retirement plan preparation for women in their thirties. In addition, the findings indicate that women who are divorced, separated, or living with a partner are more likely to contribute to their pension plans through work. Education is significant and positive as a predictor for the decision to contribute to a pension plan for women in their thirties, thus supporting our hypothesis of a significant positive relationship between education and pension plan contributions. Conversely, the findings regarding work history (length of employment and number of weeks worked per year) and the decision to contribute to a pension plan were significant and negative for women in their thirties. This result could be due to a general unconcerned attitude regarding retirement preparation in this age group since actual retirement for most is at least thirty years away. Finally, household size was insignificant as a predictor of both pension plan eligibility and the decision to contribute. Therefore, the findings do not support the hypothesis of household size as a predictor of retirement plan preparation. Thus, it appears that if individuals in large households have less discretionary income to spend on certain items, contributions to a retirement plan does not seem to be influenced by family size.

About the Authors: Dr. Kabir Hassan is a tenured professor at the University of New Orleans and also holds a visiting research professorship at Drexel University, Philadelphia. He is a financial economist with consulting, research and teaching experiences in development finance, money and capital markets, corporate finance, investments, monetary economics, macroeconomics and international trade and finance. He has published five books, over 70 articles in refereed academic journals and has presented over 100 research papers at professional conferences globally.

Dr. Shari Lawrence is an Assistant Professor of Finance in Nicholls State University. Before coming to Nicholls State University in 2005, Lawrence taught at the University of New Orleans and worked as a financial planner and retirement plan administrator for Asset Planning Services. Keywords: retirement, financial planning

\footnotetext{
The views expressed are those of the individual author and do not necessarily reflect official positions of Networks Financial Institute. Please address questions regarding content to M. Kabir Hassan at Kabir_Hassan@comcast.net. Any errors or omissions are the responsibility of the author.

NFI working papers and other publications are available on NFI's website (www. networksfinancialinstitute.org). Click "Research" and then "Publications/Papers."
} 


\section{An Analysis of Financial Preparation for Retirement M. Kabir Hassan and Dr. Shari Lawrence}

\section{INTRODUCTION}

Previous research on the subject of retirement planning has focused almost exclusively on individuals without acknowledging that there may be substantial differences between men and women regarding this subject. In this paper, we look at gender differences in financial preparation for retirement between men and women in the thirty to thirty-nine year age group. We focus specifically on this age group because it is during these formative earning years when the utility derived from saving for retirement is greatest due to the time value of money. To put this in perspective, a thirty- year old who saves $\$ 2,031$ a year toward retirement would be able to retire with a nest egg totaling $\$ 350,000$, at age sixty-five, assuming an $8 \%$ annual return. In contrast, a forty year old would have to save over twice as much or $\$ 4,788$ per year to reach this same goal. If one waited until age fifty to begin saving for retirement, $\$ 12,890$ would have to be saved per year in order to reach the $\$ 350,000$ account balance. Thus, we feel it is imperative to reach younger individuals in their prime earning years to attempt to motivate them to save for their retirement. Finally, since women may face unique challenges, compared with men, regarding retirement preparation, we feel it is worthwhile to study potential differences in retirement preparation between the sexes.

\section{GENDER DIFFERENCES}

Why are women any different from men when it comes to retirement preparation? The answer to this question is multifaceted. Some possible reasons are discussed in this section.

\subsection{WOMEN LIVE LONGER}

On average, women live about seven years longer than men. ${ }^{1}$ In addition, women are generally healthier compared to their male counterparts. Therefore, women's financial needs during retirement tend to be greater than those of men. To make the situation worse, older women are three times more likely to be widowed compared to men, which means their household income will likely decrease at some point during their retirement years. 
A woman born in 2006 can reasonably expect to live to about $80 .^{2}$ This means that a woman needs 15 years of retirement capital from all sources (assuming retirement at age 65). However, many demographers predict that many women will live into their 90's or beyond, thereby putting additional strain on their retirement resources. Indeed, one fear that looms larger among women is that they may actually outlive their retirement savings.

\subsection{SINGLE OR DIVORCED WOMEN MAY HAVE LONGER WORK LIVES COMPARED TO MEN}

Approximately, 25 million single women spend a greater portion of their lives single rather than married or with no "significant other". Due to the earnings gap as well as the financial consequences of divorce, many single and divorced women are forced to work well into what is traditionally thought of as their retirement years. Whereas the earnings gap affects single and divorced women alike, those who have gone through a divorce may be particularly vulnerable financially as a result of their divorce settlement. For example, many divorced women are saddled with expensive houses received as part of the divorce settlement in lieu of a portion of their husband's retirement benefits. Thus, working longer may be a financial necessity for some women due to life choices they have made. Although they could downsize, many women are reluctant to give up the life style and social standing associated with their current home and neighborhood.

\subsection{WOMEN HAVE MORE INTERRUPTED WORK HISTORIES}

Women tend to have interrupted work histories compared with men. The reason is that women are also more likely to either delay or take time off from their careers for child rearing. Women are more likely to interrupt their careers to care for a sick relative. In fact, the American Association of Retired Persons (AARP) finds that the vast majority (three out of four) of caregivers are women, who make changes in their working history to accommodate the ill or disabled relative or spouse. ${ }^{3}$ This decision results in fewer promotions and fewer opportunities.

According to the Social Security Administration, men work for an average of 44 years; however, women work for an average of 32 years. $^{4}$ Every year that you work fewer months 
means less retirement income. The result is that women will contribute less toward their retirement compared to men because they will ultimately have fewer overall years of service.

\subsection{WOMEN EARN LESS THAN MEN}

In general, women earn less than men. Although the earnings gap has gradually narrowed over the last couple of decades, as recently as 2002, women earned seventy-eight cents for every dollar a man earned (Rich, 2004). However, more and more women are breaching the glass ceiling. As women rise up on the corporate ladder into positions of greater authority, their potential income will grow over time. Unfortunately, inadequacies exist in the compensation system, which provides less salary for women.

According to the Bureau of Labor Statistics (2003), there are several factors contributing to the earnings gap. These include personal choices, occupational crowding, discrimination, and occupation. Researchers at the BLS found that occupation was the largest contributor to the

earnings gaps. ${ }^{5}$ The reason is that male dominated occupations and predominately male industries such as construction and manufacturing pay higher wages.

The bottom line is that the more you earn, the more you should be able to save for retirement. Therefore, women are at a disadvantage in retirement preparation compared to men due to the earnings gap. Indeed, this is based on the assumption that women are targeting equal retirement incomes compared to men. Otherwise, someone earning less income would require less retirement income to replace work income.

\subsection{MORE WOMEN MAY FACE POVERTY UPON RETIREMENT}

Compared to men, more women face poverty upon retirement. There are several factors contributing to this problem including, divorce, death of a spouse, the earnings gap, and interrupted work lives for women.

According to the National Economic Council (1998), elderly unmarried women, categorized as widowed, divorced, separated, and never married, had median income of \$11,161 in 1997, compared to elderly unmarried men having a median income of $\$ 14,769$; however, elderly married couples had a median income of $\$ 29,278$. Unfortunately, the poverty rate for unmarried elderly women was about 19 percent. 


\subsection{WOMEN INVEST MORE CONSERVATIVELY}

On average, women are more risk averse than men. Indeed, Jianakoplos and Bernasek (1996) find women hold a smaller proportion of their portfolios in risky assets. Single women are especially reluctant to hold risky assets. Investment advisors "believe" that women should receive conservative financial advice. Whether they think women will not understand a weighted portfolio analysis or a dividend growth model or just want to discriminate due to prejudice is unknown. Why women should be told to select "widows and orphans" types of investments, rather than investments that are offered to men with similar education, training, and wealth is a mystery. Many women believe they should not hold assets that are perceived as being risky. In addition, women are much more likely to be risk intolerant, by wanting to hold assets that they can rely upon for many years. Manipulating a stock account with options and futures trading considerations is foreign to the typical woman. The reality of the situation is that a system of investing more conservatively over time results in a lower overall account balance.

According to Bajtelsmit and Bernasek (1996), “biological determinism” interferes with a woman's investment opportunities. They assert that an analysis of gender restrictions has not produced a clear basis for these popular beliefs. A related study by Merrill Lynch, Inc. found that women tend to trust their instincts more than men when it comes to investment decisions. ${ }^{6}$ In addition, Merrill Lynch's results indicate that women make fewer mistakes and are better at letting go of a bad stock decision, compared to men. One can therefore conclude that although many women may lack the confidence to actively invest in the stock market or make risky investment decisions, those that are more risk tolerant are doing a good job with their portfolios.

Finally, the trend towards defined contribution plans versus defined benefit plans will force women to take a greater role in planning for their financial future. The firm that once made all the investment decisions regarding the employer-sponsored retirement plan is gradually shifting this burden to the employee. Another problem is that women traditionally have not worked at firms that provided pension plans of any type. For women who do have pension plans in which they are required to make investment choices, their risk adverseness results in a lesser return on invested capital, which causes less potential income for their retirement years. 


\subsection{FEWER WOMEN HAVE PENSIONS}

More women work in jobs that traditionally do not offer pension benefits. For example, the service and retail industries that are dominated by women typically do not rank high in the area of pension benefits. The manufacturing industry, on the other hand, which is dominated by men, consists mainly of jobs with full pension benefits. In addition to the problem of traditional female professions lacking in pension benefits, more women tend to work part-time compared to men. This is another reason why fewer women have pensions since part-time employees usually are not eligible to participate in company sponsored pension plans because they do not meet the minimum hourly requirements.

For women who do have pensions, the benefit amount is significantly lower compared to men. According to the National Economic Council (1998), the median annual private sector annuity benefit for women in 1993-94 was $\$ 4,800$, compared to median annual benefit of $\$ 9,600$ for men. For women approaching retirement, pension wealth is much smaller as well. For example, the average pension wealth for single women was just 34 percent of men's average pension wealth.

Logically, the pension gap between men and women will close as more women receive pensions and will demand that their pension checks continue to flow during their longer life spans. As a result, greater influence and observation will be placed on the long-term duration of the pension's assets.

\subsection{WOMEN MAY FEEL PRESSURE BY THEIR SPOUSES TO RETIRE EARLY}

Many women chose to begin careers after their children have grown or have reached school age. In addition, women are typically a few years younger than their spouses are. What can happen in a household is that the women may just be reaching her career potential when her husband is getting ready to retire. Not wanting to spend his retirement years sitting home waiting for his wife to come home from work, a husband may pressure his wife to retire early. This results in a dual problem for women trying to accumulate retirement savings on their own. First, they began saving later in life compared to their spouse. Second, they are retiring with less time on the job compared to their spouse and consequently have accumulated less retirement savings. 


\subsection{HEALTHCARE COSTS}

Soaring healthcare cost has become a real issue for retirees and preretirees alike. Rising medical costs and the quality of care is a concern for most women. In addition, women are more likely to end up disabled versus becoming unemployed whereas the opposite condition is true for men. ${ }^{7}$ Uninsured women have a great risk of poverty from hospitalization caused by heart or cardiovascular disease, diabetes or cancer. The costs are in the hundreds of thousands of dollars. Consequently, women will postpone seeking care, which may result in aggravation of a medical condition, costing even more money. These conditions are especially true for minorities, who may even fail to have a prescription filled at the pharmacy.

A 2006 survey by Kaiser Health Maintenance Organization finds that white women have a greater concern than minority women about the affordability of health care. ${ }^{8}$ The Bush Administration's efforts to promote Health Savings Accounts have not registered with most Americans, who do not know how the proposal would work. More and more women have no medical insurance coverage. The lack of affordable health care has become so acute in the United States that retires are fearful for their long-term well-being.

The bottom line regarding retirement planning is that individuals must factor rising healthcare cost into their savings goals. Otherwise, they may end up being short of funds during retirement. This issue is of particular importance for women since they have longer life spans on average, typically have more medical care throughout the course of their lives, and are more likely to spend time in a nursing home.

\section{PRIOR RESEARCH}

Previous research has shown gender differences in investing for retirement. Bajtelsmit and Bernasek (1996) summarize explanations for gender differences in economics, sociology, education, and gender studies. They conclude that all explanations of gender differences have their root in discrimination and/or differences in individual preferences.

Recent studies focusing on the investment habits of men and women (Bajtelsmit \& VanDerhei, 1996; Hinz, McCarthy \& Turner, 1996; Jianakoplos \& Bernasek, 1996), have found that women are more risk averse than men. For example, Hinz, McCarthy, and Turner 
conducted a study using 1990 survey data involving 498 participants in a defined contribution plan for government workers. The results of their logit analysis indicate that men are significantly more likely to hold risky assets in their pension plans. Bajtelsmit and VanDerhei (1996) analyze 1993 plan level data from 20,000 management level employees regarding investment allocation. Their findings indicate that women are significantly more likely to allocate their pension assets to fixed income alternatives.

Jianakoplos and Bernasek (1996) use data from the 1989 Survey of Consumer Finances to measure risk aversion between men and women. They regressed the holdings of risky assets as a percentage of total assets on the natural log of wealth and other explanatory variables, based on a theoretical framework developed Friend and Blume (1975). The results of Jianakoplos and Bernasek's study illustrate that single women are most risk averse as 63\% reported they are not willing to take any financial risk at all. Furthermore, 57\% of married women reported they were unwilling to take any financial risk, followed by $43 \%$ of single men and $41 \%$ of married men.

Burkhauser and Duncan (1989) analyze the correlation between life events and income loss over the life cycle. They find that women face a greater risk of experiencing a decrease in well-being relative to men. The authors indicate that this is due to the uneven protection provided by social security. Additional results indicate that the experiences of men and women across their lifetimes are very different. Although the income-to-needs ratios for the youngest men and women are essentially the same, thereafter the ratio falls dramatically for women compared to that of men. Furthermore, the risk of a decrease in income to a near-poverty level is consistently greater for women, especially during the childbearing years. Hence, one can conclude that women on average are not as adequately prepared for retirement compared to men.

Whereas the aforementioned study gives an overview of life cycle patterns of family income, this study will look specifically at men and women in their thirties. This is a decade when retirement planning should be a priority as the earlier one begins saving for retirement the greater the monetary reward due to the time value of money. Hence, people should be maximizing their retirement plan contributions during these years. Rather than looking at the impact of life events on retirement preparation, however, our focus is on how socioeconomic variables correlate with retirement preparation of men and women. 
Several studies have used the life-cycle model of savings as a basis for analyzing the effects of various socio-demographic events on retirement economic well-being. According to the life-cycle model of savings, income does not necessarily flow into the family at the rate necessary to meet current expenditures. As a result, there will be periods in the life cycle when expenditures exceed income, forcing the family to dissave by borrowing or using previously acquired assets. These periods of dissaving usually occur in both the early and late periods of the life cycle. Using longitudinal profiles from 1900-1974, Kotlikoff and Summers (1981) findings suggest that expenditures are parallel to income prior to age 45, resulting in relatively little savings or dissavings. However, the findings indicate that there is positive savings between ages 45-60 and negative savings from age 60 onward.

Although the basic life-cycle model suggests that there will be savings, academic views differ regarding the underlying reasons for this savings. James Duesenberry's relative income theory hypothesizes that in the end, there is a direct relationship between an individual's income and consumption habits and those of his peers. Thus, consumers are less responsive to short-run changes in income levels since, in general, they continue to maintain similar consumption habits. Likewise, Milton Friedman's permanent income theory explains that short-run income changes are not immediately incorporated into an individual's estimate of permanent income. However, individuals gradually adjust to such changes and therefore will adjust their consumption habits accordingly in the end. Ando and Modigliani adapted Freidman's permanent-income concept when developing their life-cycle hypothesis. The main concept of the life-cycle model is that a rational consumer will make decisions over his or her lifetime rather than over a shorter time horizon. Using the original life-cycle model, Ando and Modigliani (1963) and Modigliani and Brumberg (1954) explain that the purpose of savings resulted from the need to defer consumption from income earning years until retirement, when income typically falls. However, one criticism of this theory is that there is limited evidence that retired individuals actually dissave (Leland, 1968). Indeed, the life cycle model itself has been used to explain the tendency of younger people to have significantly higher levels of consumption (dis-savings) than older people do, even though their income levels are similar.

Another view is that the purpose of saving is to protect against future unexpected variations in income and interest rates as well as changes in the tax law, pension rules and the 
uncertainty regarding life expectancy. Therefore, individuals will consume less when they are younger in order to build up savings for the future in case there are adverse circumstances. Several studies have examined the effect of the aforementioned uncertainties on consumption and savings (Flavin, 1981; Friedman, 1957; Kotlikoff and Summers, 1981; Leland, 1968; and Skinner, 1987). For example, Skinner's findings, with data from the Consumer Expenditure Survey, indicate that $56 \%$ of aggregate life-cycle savings are precautionary savings. Moreover, there is the view that savings is an accumulation of wealth to be transferred to other generations. It is believed that these transfers are motivated by altruistic reasons, whereby, parents or children transfer wealth in order to offset public policies causing public debt or future Social Security Burdens (Barro, 1974; Becker, 1974). Another motivation is the utility derived from bequests (Yaari, 1965). In addition, parents may use transfers as a way of inducing their children to take care of them later in life. However, according to Modigliani (1988) the bequest motive for savings, whether altruistic or not, is below $25 \%$ of total savings. Finally, whether the motive for savings is retirement, precautionary or intergenerational transfers, all of the models predict that individuals will defer consumption in their younger to middle aged years.

The studies mentioned thus far have mainly examined bivariate relationships between prior characteristics or events and eventual retirement. However, Palmore, George and Fillenbaum (1982) use multivariate analysis to study the predictors of retirement. The authors attempt to answer the question, "What factors best predict retirement?" Their study is significant because in addition to multivariate analysis, multiple data sets, multiple definitions of retirement, longitudinal data and statistical techniques allowing unbiased analysis of dichotomous dependent variables are also used.

The studies using multivariate analysis suggest five groups of predictors that are related to retirement: demographic characteristics, socioeconomic status, health, job characteristics, and attitudes toward work and retirement. Palmore, George and Fillenbaum (1982) compare the importance of structural variables to subjective variables in predicting both early and normal retirement for men. The structural variables are defined as demographic, socioeconomic and job characteristics. Conversely, self-rated health and attitudes make up the subjective variables. The earlier studies by Parnes and Nestel (1971) and Bixby (1976) find subjective variables to be more significant as predictors of early retirement. However, Bixby (1976) finds both subjective 
and structural variables to be equally significant for those retiring at normal retirement age. Conversely, Palmore (1971) finds subjective variables to be more statistically significant.

Palmore, George and Fillenbaum (1982) present their results, regarding retirement predictors for men, from the Retirement History Study (RHS) and the National Longitudinal Surveys (N.S.). The Social Security Administration conducted the RHS for the years 1969 to 1979. The sample consists of 11,153 men and unmarried women aged 58-63 (Murray, 1979). Furthermore, the N.S. were conducted for the Department of Labor by the Center for Human Resources Research at Ohio State University during the years 1966 to 1976. The sample size is 5,020 men age 45-59 (Parnes, 1981). The groups of variables to be tested were arranged in the following categories: demographic, socioeconomic status (SES), health, job characteristics, and attitudes.

Using multiple regression analysis, the authors find that age is the only statistically significant demographic predictor of objective retirement. That is, for those who are not retiring early, age is the only statistically significant demographic predictor. All of the other demographic variables tested (race, marital status, region, rural-urban residence) were not significant predictors of objective retirement.

All of the SES predictors (education, occupation, poverty ratio) are statistically significant as predictors of retirement. The findings indicate that higher SES men have more opportunities and incentives to work past the normal retirement age of 65. Regarding the health variables, none of these were found to be significant. However, job characteristics were found to be statistically significant. According to the findings using data from the RHS, jobs that provide pension plans and jobs with mandatory retirement were the two strongest predictors of retirement. Moreover, being employed by others, as opposed to being self-employed, was the strongest predictor of retirement according to the NLS data. Finally, retirement attitudes were not statistically significant in either data set. Other studies of objective retirement have found fewer significant predictors. This is probably because the samples were smaller. In conclusion, the studies indicate that structural factors such as SES and job characteristics are stronger predictors of objective retirement, for those over age 65, than subjective characteristics of health self-rating and retirement attitude. 
Conversely, the results of predictors of early retirement (objective retirement before age 65) are different from the normal retirement findings. Specifically, in both data sets the health variables are significant as predictors of early retirement whereas job characteristics are less significant. In addition, retirement attitude is more significant according to the NLS data. Other studies have yielded similar results, however, fewer variables are significant overall as predictors of early retirement.

Palmer, George, and Fillenbaum's (1982) conclusions are compatible with the findings of earlier studies (Bixby, 1976). However, the previous studies were limited due to methods and samples used. The general conclusions are that early retirement is influenced more by subjective factors such as attitudes about health, work, retirement, and the perceived adequacy of retirement income. The reason is that retirement is usually neither expected nor mandated before age 65 . Conversely, many workers over age 65 are pressured to retire by society's expectations and mandatory retirement policies. As a result, only those who are self employed or in jobs that do not have mandatory retirement are able to continue working. The authors' interpretation is compatible with Parnes' (1981) conclusion. That is, early retirement is most often due to health reasons and normal retirement is due to mandatory retirement rules or pressure by employers, coworkers and family.

Regarding education programs on retirement planning, a 1996 survey by Buck Consultants, Inc. on work and family programs and policies analyzed the impact of employee benefits in the workplace. The results obtained from 313 firms indicate that a higher percentage of women than men consistently react favorably to employee benefit programs. Therefore, with an increased number of women in the workforce, employers should seriously consider the implementation of employee benefit plans, including retirement plans, to remain competitive and increase employee morale and retention, particularly among women.

A more recent study by Clark, d'Ambrosio, McDermed, and Sawant (2003) finds similar results to those of the 1996 survey by Buck Consultants, Inc. Indeed, Clark, et al. find that women are much more likely to alter their retirement goals and saving behavior after attending education seminars on retirement planning. The behavioral changes include pushing back retirement dates, increasing retirement plan contributions, and changing investment strategies. This study is also meaningful in another sense. That is, it illustrates how important financial 
education is in assisting individuals in reaching their retirement goals. Once people are able to get a realistic picture of their financial needs upon retirement, they can then develop an adequate savings plan in order to achieve their long-term goals.

\section{DATA}

The data for this study were obtained from the 1995 Survey of Consumer Finances (SCF) available from the Federal Reserve System in cooperation with the Statistics of Income Division at the Department of Treasury. The SCF is a triennial type of survey and is designed to provide information on households regarding their personal finances, pension plan coverage, labor force participation, and various demographic characteristics. In order to provide accurate information on characteristics that are widely distributed in the population as well as characteristics that are concentrated in a small part of the population, such as home ownership versus investment in real estate, a dual frame sample design is used. The purpose is to provide an adequate descriptive base for the analysis of household assets and liabilities. The first part is a geographically-based standard multistage probability sample whereas the second part is a special over-sample of wealthy families taken from tax records. The second part is necessary because wealthy families hold a disproportionately large share of certain assets, such as tax exempt bonds. The response rate is approximately $70 \%$ for the standard probability sample and about $34 \%$ for the special sample. The survey was conducted by the National Opinion Research Center at the University of Chicago. The Survey consists of 4,299 households, 2,780 from the area probability sample and 1,519 from the list sample. Furthermore, the time frame for the interviews averaged 90 minutes. In addition, there are 4,967 variables and 21,495 observations in the survey. Aside from demographic characteristics, other variables in the survey encompass detailed information on financial assets, nonfinancial assets, and liabilities. Some examples include information on savings bonds, stocks, mutual funds, retirement accounts, life insurance, vehicles, real estate, business assets and credit card debt.

In order to accommodate for non-response error, statistical methods were used by the Federal Reserve Board to impute the missing data before the survey was released to the public. Specifically, the missing data in the survey was imputed five times by drawing repeatedly from an estimate of the conditional distribution of the data. These imputations are stored as five 
successive replicates of each data record. Thus, the number of observations in the data set, 21,495, is five times the actual number of respondents, 4299.

\section{METHODOLOGY}

The data used for the study is a sub-sample of men and women aged 30-39 from the 1995 Survey of Consumer Finances. The data were separated into two groups consisting of men and women (respondents and spouses) aged 30-39. Probit analysis was used with the multiple regression model to observe the statistical significance of socio-demographic variables on retirement savings.

$$
\mathrm{y}_{\mathrm{i}}=\alpha+\beta_{1} \mathrm{x}_{1 \mathrm{i}}+\beta_{2} \mathrm{x}_{\mathrm{si}}+\ldots+\beta_{\mathrm{k}} \mathrm{x}_{\mathrm{ki}}+\mathrm{u}_{\mathrm{i}}
$$$$
\mathrm{i}=1,2, \ldots, \mathrm{n}
$$

The probit model was chosen because a binary choice model is most applicable for testing our hypotheses. The binary choice of the $i$ th variable is represented by a random variable $\mathrm{y}_{\mathrm{i}}$ and takes the value of 1 if one choice is made and 0 if the other choice is made.

The dependent variables for analysis were grouped into two categories:

1) whether or not the individual is eligible for a retirement plan (ELIG)

2) whether or not the individual is contributing (CONTRIB) to a retirement plan.

Thus, if an individual is eligible to participate in a retirement plan, the random variable $\mathrm{y}_{\mathrm{i}}$ takes the value of 1 . If an individual is not eligible for a retirement plan, $\mathrm{y}_{\mathrm{i}}$ takes the value of 0 . Likewise, if an individual is contributing to a retirement plan $\mathrm{y}_{\mathrm{i}}$ takes the value of 1 , or 0 otherwise.

The variables for ELIG are comprised of data from responses to the survey question listed below.

1) Aside from IRA or Koegh plans, are you included in any pension plans through work? The variables for CONTRIB are taken from responses to the following survey question:

1) Are you currently making contributions to your pension plan through work? 
The independent variables used in this study are described in the appendix. Note that the number of independent variables was reduced due to errors associated with multicollinearity.

Regarding the subgroup of women, the hypothesis is as follows:

W1) Education, occupation, income, marital status, work history, good health, and household size are statistically significant variables affecting eligibility for and contributing to a retirement plan for women age 30-39.

Regarding men, the factors affecting retirement savings are as follows:

M1) Education, income, good health, work history, household size, and occupation are statistically significant variables affecting eligibility for and contributing to a retirement plan for men age 30-39.

For each subgroup, age and income are hypothesized to be directly related to total retirement savings. In addition, work history is hypothesized to be directly related to retirement savings. In contrast, the relationship of household size to retirement savings is hypothesized to be negative. Finally, because men tend to have longer and uninterrupted work histories compared to women, their overall retirement savings is expected to be greater. Table 1 provides a description of the variables used in this study.

\section{FINDINGS}

Table 2 provides probit regression for the dependent variable defined previously as ELIG and all of the various independent variables. Differences in retirement preparation between men and women in their thirties are analyzed.

Regarding men in their thirties, the findings indicate that good health and length of employment have significant positive effects on retirement plan eligibility. In addition, household size and income combined with age have significant positive effects on pension plan eligibility for men. However, the effect of income alone and the number of weeks worked per 
year is significantly negative on retirement plan eligibility for men in their thirties. Regarding marital and household status among men in their thirties, the findings indicate no significance among pension plan eligibility and these variables.

The results pertaining to women in their thirties indicate that income, good health, and work history (length of employment and the number or weeks worked per year) have significant positive effects on pension plan eligibility. Therefore, the findings generally support the hypothesis of the aforementioned variables as a predictor of retirement plan preparation for women in their thirties. In addition, significant positive effects regarding pension plan eligibility are reported for divorced women, although the results were not significant for women who were either married or separated. Regarding household status, the findings indicate a significant positive relationship between pension plan eligibility and women who are homeowners. However, the findings indicate a negative relationship between eligibility in a retirement plan and women who are renters. Additional findings indicate the age and education levels have significant negative effects regarding pension plan eligibility for both sexes in their thirties.

Table 3 presents probit analysis for the dependent variable previously defined as CONTRIB in which respondents were asked if they are currently making contributions to their pension plans. The tests for this dependent variable did not yield meaningful results for men due to the small sample size. However, the results obtained for women are described below.

The strongest results are the findings for the income, education, health variables, and the decision to contribute to a pension plan. Indeed, the results indicate significant positive effects regarding income, the level of education, and good health among women in their thirties who are making contributions to their pension plans, thus supporting our hypothesis. These results are consistent with the findings of Palmore, George, and Fillenbaum (1982) and Parnes and Nestel (1971). Individuals in good health may be more productive in the workplace leading to higher income levels thereby enabling them to contribute more toward retirement. In addition, less discretionary income is spent on medical services as opposed to individuals in poor health. Thus, more income is available to put into a retirement plan. Finally, better educated individuals may be more informed about the benefits of retirement savings and are therefore willing to contribute larger amounts to their pension plans compared to individuals with less education. 
The findings indicate significant and positive results regarding the decision to contribute to a pension plan among women who are divorced, separated, or living with their partner. Note however, the results are not significant regarding the contribution variable and married women. These findings may illustrate the forced need for women who are not married to save for retirement on their own due to their marital status. Conversely, married women do not have to rely solely on their retirement as they are able to benefit from their husband's pension plan.

The findings regarding work history (length of employment and number of weeks worked per year) and the decision to contribute to a pension plan are significant and negative for women in their thirties. Finally, household size, net worth, age, and home ownership are not significant as a predictor of the decision to contribute to a pension plan among women in their thirties.

\section{CONCLUSION AND POLICY IMPLICATIONS}

The purpose of this study is to examine the differences in retirement preparation between men and women in their thirties. Probit analysis was conducted using data from the Survey of Consumer Finances. The findings indicate that women in their thirties have higher reported income than men of the same age group. In addition, the majority of respondents were homeowners.

The main findings regarding pension plan eligibility indicate that good health and work history have significant positive effects on retirement plan eligibility for men and women in their thirties. However, income has a significant positive effect on retirement plan eligibility only for women in this age group as the effect was significantly negative for men. Furthermore, significant positive effects regarding pension plan eligibility were reported for divorced women. This may be the result of a disproportionate amount of divorced women in the workforce compared to married women. Finally, age and education levels have significant negative effects for both sexes in their thirties.

The findings regarding retirement plan contributions indicate significant positive effects regarding income and women in their thirties who are making contributions to their pension plans. Therefore, the findings generally support the 
hypothesis of income as a predictor of retirement plan preparation. In addition, the results are significant and positive for contribution rates among women who are divorced, separated, or living with their partner. Moreover, education is significant and positive as a predictor of the decision to contribute to a pension plan for women in their thirties, thus supporting our hypothesis.

The findings regarding work history (length of employment and number of weeks worked per year) and the decision to contribute to a pension plan are significant and negative for women in their thirties. Finally, household size is insignificant as a predictor of the decision to contribute for women in their thirties and therefore does not support the hypothesis of this variable as a predictor of retirement plan preparation.

The findings have policy implications for public policy makers, practitioners, employers, and educators. The government can promote higher pension plan eligibility rates by making the rules governing entry into company-sponsored pension plans more lenient. In addition, policies that encourage firms to include features in their retirement plans that promote employee contributions, such as greater tax benefits for higher employer matching rates, should be instituted.

Practitioners and employers would benefit by better educating employees about the firm's retirement plan. Specifically, clear lines of communication must be established among employees, employers, and practitioners in order to promote the benefits of saving for retirement. If employees understand both the tax benefits they receive by deferring part of their earnings into their retirement plan and the concept of the time value of money they should be more willing to contribute to their pension plans. This is of particular importance to women, as prior research (Clark, et al., 2003, \& Buck Consultants, Inc., 1996) indicates that women are much more likely to alter their retirement goals and savings behavior after attending an informational seminar regarding retirement planning. Therefore, it is likely that education programs would be effective in motivating women in particular to save more toward their retirement.

As far as educators are concerned, retirement planning should not be relegated to one of the last chapters in textbooks as is often the case. Rather, this 
subject should be brought to the forefront in personal finance classes as students need to realize that retirement planning is just as important for a 25 year old as it is for a 50 year old. Finally, once individuals realize this they will be more apt to begin saving for retirement at an early age, enabling them to be more financially secure later in life. 


\section{ENDNOTES}

1. Social Security Administration, Office of the Chief Actuary.

2. Bureau of Labor Statistics, Current Population Survey, September 2006.

3. American Association of Retired Persons, (AARP), October 2006, http://www.aarp.com.

4. Social Security Administration, Office of the Chief Actuary.

5. Bureau of Labor Statistics. (2003, June 18). How Gender Influences the Earnings Gap. Retrieved October 1, 2006, from

http://www.imdiversity.com/villages/woman/careers_ workplace_employment/gender_and_wages.asp

6. Merrill Lynch Investment Management Survey, a nationwide telephone poll of 500 men and $500 \quad$ women conducted in April, 2005.

7. Social Security Administration, Office of the Chief Actuary.

8. Kaiser Permanente Health Maintenance Organization, 2006. 


\section{REFERENCES}

Ando, A., \& Modigliani, F. (1963). The Life-Cycle Hypothesis of Savings: Aggregate Implications and Tests. American Economic Review 53, 55-84.

Bajtelsmit, V. L., \& Bernasek, A. (1996). Why do Women Invest Differently Than Men? Financial Counseling and Planning 7, 1-10.

Bajtelsmit, V. L., \& VanDerhei, J. A. (1996). Risk Aversion and Retirement Income Adequacy. Forthcoming in Positioning Pensions for the Twenty-First Century. Philadelphia: University of Pennsylvania Press.

Barro, R. J. (1974). Are Government Bonds Net Wealth? Journal of Political Economy 82, 1095-1117.

Becker, G. S. (1974). A Theory of Marriage Part II. Journal of Political Economy 82, 11-26.

Bixby, L. (1976). Retirement Patterns in the United States. Social Security Bulletin 39, 3-19.

Buck Consultants, Inc. (1998). 401(k) Plans. 10 ${ }^{\text {th }}$ Edition.

Bureau of Labor Statistics. (2003, June 18). How Gender Influences the Earnings

Gap. Retrieved

October 1, 2006, from

http://www.imdiversity.com/villages/woman/careers_workplace_employmen t/gender_and_wages.asp

Burkhauser, R. V., \& Duncan, G. J. (1989). Economics Risks of Gender Roles: Income Loss and Life Events Over Life Course. Social Science Quarterly 70(1), 3-23.

Clark, R. L., d’Ambrosio, M. B., McDermed, A. A., \& Sawant, K. (2003). Pension Design and

Structure: New Lessions from Behavioral Finance, Oxford: Oxford University Press.

Duesenberry, J. S. (1959). Income, Savings, and the Theory of consumer Behavior. New York: MacMillan.

Engen, E. M., Gale, W. G. \& Scholz, J. K. (1996). The Illusory Effects of Saving Incentives on Saving. Journal of Economic Perspectives 10(4), 113-138. 
Fethke, C. C. (1989). Life Cycle Models of Saving and the Effect of the Timing of Divorce on Retirement Economic Well Being. Journal of Gerontology, 44(3), 121-128.

Fillenbaum, G. G., George, L. K., \& Palmore, E. B. (1985). Determinants and Consequences of Retirement Among Men of Different Races and Economic Levels. Journal of Gerontology 40(1), 85-94.

Flavin, M. A. (1981). The Adjustment of Consumption to Changing Expectations about Future Income. Journal of Political Economy 89, 974-1009.

Friedman, M. (1957). A Theory of the Consumption Function. New Jersey: Princeton University Press.

Friend, I. \& Blume, M.E. (Dec. 1975). The demand for Risky Assets. American Economic Review, 900.

Garfinkel, I., \& McLanahan, S. (1987). Single Mothers and Their Children: A New American Dilemma. Urban Institute, Washington, D.C.

Hatcher, C. B. (1995). Wealth, Reservation Wealth, and the Decision to Retire. Consumer Interests Annual 41, 244-245.

Hatten, M. L. (1986). Macroeconomics for Management, 90-92. New Jersey: Prentice-Hall.

Hinz, R. P., McCarthy, D. D., \& Turner, J.A. (1996). Are Women Conservative Investors?: Gender Differences in Participant Directed Pension Investments. Forthcoming in Positioning Pensions for the Twenty-First Century. Philadelphia: University of Pennsylvania Press.

Hubbard, R. G. (1984). Do IRAs and Keoghs Increase Savings? National Tax Journal 37, 43-54.

Hubbard, R. G., Skinner, J., \& Zeldes, S. P. (1995). Precautionary Saving and Social Insurance. Journal of Political Economy 103(2), 360-399.

Jianakoplos, N., \& Bernasek, A. (1996). Are Women More Risk Averse? Working Paper, Colorado State University.

Kim, C. S., Wong, K. M. (1997). Asset Allocation Strategies for Personal Pension Contributions. Financial Practice and Education, 35-46.

Kokrda, E., \& Cramer, S. (1995). Factors Affecting Retirement Savings of Women in Two Age Groups. Family Economics and Resource Management Biennial, 115-120. 
Kotlikoff, L. J. (1982). The Adequacy of Savings. American Economic Review 72, 1056-1069.

Kotlikoff, L. J., \& Summers, L. H. (1981). The Role of Intergenerational Transfers in Aggregate Capital Accumulation. Journal of Political Economy 89, 706-732.

Leland, H. (1968). Savings and Uncertainty: The Precautionary Demand for Saving. Quarterly Journal of Economics 82, 465-473.

Logue, B. J. (1991). Women at Risk: Predictors of Financial Stress for Retired Women Workers. The Gerontologist 31(5), 657-665.

Maddala, G. S. (1992). Introduction to Econometrics, 327-330. New York: MacMillan.

Magenheim, E.B. (1993). Gender Related Patterns in Pensions: A Review of the Literature. U.S. Department of Labor.

Malroutu, Y. L., \& Xiao, J. J. (1995a). Financial Preparation for Retirement. Consumer Interests Annual 41, 49-54.

Malrouto, Y. L., \& Xiao, J. J. (1995b). Perceived Adequacy of Retirement Income. Financial Counseling and Planning 6, 17-23.

Modigliani, F. (1988). The Role of Intergenerational Transfers and Life Cycle Savings in the Accumulation of Wealth. The Journal of Economic Perspectives 2, 15-40.

Modigliani, F., \& Brumberg, R. (1954). Utility Analysis and the Consumption Function: An Interpretation of Cross-Section Data. Post-Keynesian Economics. New Brunswick.

Montalto, C. P., \& Sung, J. (1996). Multiple Imputation in the 1992 Survey of Consumer Finances. Financial Counseling and Planning 7, 133-146.

Murray, J. (1979). Subjective Retirement. Social Security Bulletin 42, 1-7.

National Economic Council, (1998, October 27), Women and Retirement Security.

Retrieve

October 2, 2006, from

http://www.ssa.gov/history/pdf/sswomen.pdf\#search=\%22retirement\%20wo men\%20live\%20longer\%22. 
Palmore, E. (1971). Why do People Retire? Aging and Human Development 2, 269283.

Palmore, E. B., George, L. K., \& Fillenbaum, G. G. (1982). Predictors of Retirement. Journal of Gerontology 37, 733-742.

Parnes, H. (Ed.). (1981). Introduction and Overview. Work and Retirement: A Longitudinal Study of Men, Cambridge, MA.: MIT Press.

Parnes, H., \& Nestel, G. (1971). Retirement Expectations of Middle-Aged Men. Center for Human Resources Research, Ohio State University, Columbus, Ohio.

Poterba, J. M., Venti, S. V. \& Wise, D. A. (1996). How Retirement Saving Programs Increase Saving. Journal of Economic Perspectives 10(4), 91-112.

Rich, S. (2004, August 1). Retiring Women: A Real Anxiety. On Wall Street, 1.

Rix, S. E. (1993). Women and Well-Being in Retirement: What Role for Public Policy. Journal of Women and Aging 4, 37-56.

Skinner, J. (1987). Risky Income, Life-Cycle Consumption and Precautionary Savings. Working Paper No. 2336. Cambridge, MA.: National Bureau of Economic Research.

Yaari, M. E. (1965). Uncertain Lifetime, Life Insurance, and the Theory of the Consumer. Review of Economic Studies 32, 137-150. 


\section{APPENDIX}

Table 1

Independent Variables taken from the 1995 Survey of Consumer Finances

Data taken from the 1995 SCF available from the Federal Reserve System in cooperation with the Statistics of Income Division at the Department of Treasury were used as independent variables in our analysis.

\begin{tabular}{|c|c|c|c|}
\hline \multicolumn{2}{|c|}{ Socio-Demographic Variables } & \multicolumn{2}{|l|}{ Work Related Variables } \\
\hline Age & 30-39 years & Employment & Employer \\
\hline \multirow[t]{2}{*}{ Gender } & Male & & Self employed \\
\hline & Female & & Partnership \\
\hline \multirow[t]{7}{*}{ Marital status } & Married & & Other \\
\hline & Living with partner & Length of Employment & Number of years \\
\hline & Separated & Current employment status & Full-time \\
\hline & Divorced & & Part-time \\
\hline & Widowed & & NA \\
\hline & Never Married & Length of full-time employment & Number of years \\
\hline & NA & Length of part-time employment & Number of years \\
\hline Household size & Number of persons & Full-time employment $>1$ year & Number of jobs \\
\hline Income & Amount on income & Present job status & Working \\
\hline \multirow[t]{10}{*}{ Education } & Highest grade completed & & Temporarily laid off \\
\hline & & & Unemployed \\
\hline & & & Student \\
\hline & & & Homemaker \\
\hline & & & Disabled \\
\hline & & & Retired \\
\hline & & & Volunteer \\
\hline & & & Other \\
\hline & & & NA \\
\hline & & Date last worked & Month/year \\
\hline
\end{tabular}




\section{Table 2}

Probit Analysis of Factors Affecting Retirement Plan Eligibility

A probit two-stage least squares procedure was employed using data taken from the 1995 SCF. The coefficient, marginal effect, and P values of each of the independent variables tested in relation to the dependent variable, pension plan eligibility, are listed below.

Dependent variable: Included in pension plans through work

\begin{tabular}{|c|c|c|c|c|c|c|}
\hline & \multicolumn{3}{|c|}{ Men age 30-39 } & \multicolumn{3}{|c|}{ Women age 30-39 } \\
\hline Independent Variables & Coefficient & Marginal Effect & $\begin{array}{c}\mathrm{P} \\
\text { Value }\end{array}$ & Coefficient & Marginal Effect & $\begin{array}{c}\mathrm{P} \\
\text { Value }\end{array}$ \\
\hline Length of employment & .0507 & .0202 & .0000 & .0331 & .0130 & .0000 \\
\hline \multicolumn{7}{|l|}{ Age } \\
\hline Respondent & -.1310 & -.0523 & .0000 & -.0735 & -.0289 & .0000 \\
\hline Spouse & -.0078 & -.0031 & .3371 & .0045 & 0.0018 & .0228 \\
\hline \multicolumn{7}{|l|}{ Marital status } \\
\hline Married & -.0560 & -.0224 & .8477 & -.0944 & -.0370 & .3152 \\
\hline Living with partner & -.2194 & -.0875 & .4726 & -.3373 & -.1323 & .0007 \\
\hline Separated & -.3653 & -.1457 & .1334 & .0856 & .0336 & .3581 \\
\hline Divorced & .1767 & .0705 & .2897 & .3310 & .1298 & .0000 \\
\hline Household size & .1194 & .0476 & .0000 & -.0057 & -.0022 & .6742 \\
\hline \multicolumn{7}{|l|}{ Income } \\
\hline Respondent & -.0000 & -.0000 & .0895 & .0000 & .0000 & .0004 \\
\hline Spouse & -.0000 & -.0000 & .0095 & .0000 & .0000 & .6070 \\
\hline Education of Respondent & -.3081 & -.1229 & .0000 & -.1800 & -.0706 & .0000 \\
\hline \multicolumn{7}{|l|}{ Respondent's health } \\
\hline Good & .3737 & .1491 & .0008 & .1295 & .0508 & .0056 \\
\hline Excellent & .4202 & .1676 & .0003 & .1828 & .0717 & .0001 \\
\hline \multicolumn{7}{|l|}{ Household status } \\
\hline Rent & -.1145 & -.4569 & .4377 & -.1647 & -.0646 & .0163 \\
\hline Own & -.0858 & -.0342 & .5451 & .1791 & .0702 & .0060 \\
\hline $\begin{array}{l}\text { Number of weeks worked } \\
\text { per year }\end{array}$ & .0209 & .0083 & .0038 & .0112 & .0044 & .0000 \\
\hline Age * Education & .0088 & .0035 & .0000 & .0038 & .0015 & .0000 \\
\hline Age $*$ Income & .0000 & .0000 & .0368 & -.0000 & -.0000 & .0003 \\
\hline Age $*$ Net worth & -.0000 & -.0000 & .2618 & -.0000 & -.0000 & .0000 \\
\hline \multicolumn{4}{|c|}{ Men age 30-39: $\quad$ Log Likelihood $=-1264.853$} & \multicolumn{3}{|c|}{ Predictability $=.76$} \\
\hline \multicolumn{2}{|c|}{ Women age 30-39: Log Likelihood $=-6174.538$} & Chi-squared $=4379.2$ & & \multicolumn{3}{|c|}{ Predictability $=.76$} \\
\hline
\end{tabular}


Table 3

Probit Analysis of Factors Affecting the Decision to Contribute to Employer Sponsored Retirement Plans

A probit two-stage least squares procedure was employed using data taken from the 1995 SCF. The coefficient, marginal effect, and P values of each of the independent variables tested in relation to the dependent variable, pension plan eligibility, are listed below.

Dependent variable: Is employee currently contributing to plan?

\begin{tabular}{|c|c|c|c|}
\hline & \multicolumn{3}{|c|}{ Women age 30-39 } \\
\hline Independent Variables & Coefficient & Marginal Effect & P Value \\
\hline Length of employment & -.0076 & -.0029 & .0478 \\
\hline Respondent's age & -.0026 & -.0010 & .8068 \\
\hline Spouse's age & .0055 & .0021 & .3536 \\
\hline \multicolumn{4}{|l|}{ Marital status } \\
\hline Married & .2744 & .1058 & .3220 \\
\hline Living with partner & 1.080 & .4164 & .0007 \\
\hline Separated & .4080 & .1573 & .0686 \\
\hline Divorced & .6229 & .2410 & .0000 \\
\hline Household size & -.0101 & -.0039 & .7638 \\
\hline \multicolumn{4}{|l|}{ Income } \\
\hline Respondent & .0001 & .0000 & .0000 \\
\hline Spouse & -.0000 & -.0000 & .3594 \\
\hline Respondent's education & .0614 & .0237 & .0792 \\
\hline \multicolumn{4}{|l|}{ Respondent's health } \\
\hline Good & .4551 & .1755 & .0003 \\
\hline Excellent & .4660 & .1797 & .0002 \\
\hline \multicolumn{4}{|l|}{ Household status } \\
\hline Rent & .4455 & .1718 & .0264 \\
\hline Own & .0919 & .0353 & .6292 \\
\hline Net worth & .0000 & .0000 & .8148 \\
\hline Number of weeks worked per year & -.0427 & -.0165 & .0000 \\
\hline Age * Education & .0001 & .0005 & .8651 \\
\hline Age * Income & -.0000 & -.0000 & .0000 \\
\hline Age * Net worth & -.0000 & -.0000 & .7965 \\
\hline Women age 30-39: Log Likelihood $=-1163.221$ & Chi-squared $=386.3752$ & Predictability $=.66$ & \\
\hline
\end{tabular}

